\title{
HUBUNGAN KESUKAAN DAN KESEDIAAN DENGAN KONSUMSI SAYUR DAN BUAH PADA REMAJA
}

\author{
Rinawati Tarigan \\ AKPER Malahayati Medan , Jl. Cendrawasih No. 161 Sei Sikambing B Medan \\ Email: rinawati75@gmail.com
}

\begin{abstract}
ABSTRAK
Kecukupan konsumsi sayur dan buah pada remaja dipengaruhi oleh berbagai alasan seperti tidak suka, keluarga tidak menyediakan karena ekonomi, kantin sekolah kurang menyediakan dan lain-lain. Hasil survei awal diketahui $80 \%$ siswa laki-laki dan 37,5\% siswa perempuan kurang mengonsumsi sayur dan buah. Tujuan penelitian untuk menguji hubungan kesukaan dan kesediaan dengan konsumsi sayur dan buah siswa. Penelitian ini bersifat kuantitatif menggunakan desain penelitian cross-sectio yang dilaksanakan di SMK Negeri 1 Percut Sei Tuan Kabupaten Deli Serdang. Sampel adalah seluruh siswa kelas XI dan kelas XII Jurusan Rekayasa Perangkat Lunak SMK Negeri 1 Percut Sei Tuan Kabupaten Deli Serdang tahun 2019 sebesar 97 orang. Alat pengumpulan data menggunakan kuesioner. Uji yang digunakan adalah chi-square. Hasil penelitian menunjukkan bahwa ada hubungan antara konsumsi sayur dengan kesukaan ( $p=0,001, R P=5,47)$, dan ketersediaan $(p=0,173)$. Ada hubungan antara konsumsi buah dengan kesukaan ( $p=0,001, R P=2,47)$, dan ketersediaan ( $p=0,006, R P=2,79)$. Peneliti menyarankan kepada keluarga khususnya orang tua untuk meningkatkan kesediaan sayur dan buah setiap hari dirumah untuk membentuk kesukaan remaja pada sayur dan buah.
\end{abstract}

Kata Kunci: Kesukaan, Ketersediaan, konsumsi sayur dan buah

\section{ABSTRACT}

Adequacy of consumption of vegetables and fruit in adolescents is influenced by various reasons such as dislike, the family does not provide because of the economy, the school canteen lacks supply and others. The initial survey results found that $80 \%$ of male students and $37.5 \%$ of female students consumed less vegetables and fruit. The purpose of the study was to examine the relationship of preference and willingness to the consumption of vegetables and fruits of students. This research is quantitative using a cross-sectional research design conducted at SMK Negeri 1 Percut Sei Tuan, Deli Serdang Regency. The sample was all students of class XI and class XII of the Department of Software Engineering at SMK Negeri 1 Percut Sei Tuan in Deli Serdang in 2019 amounting to 97 people. Data collection tool uses a questionnaire. The test used was chi-square. The results showed that there was a relationship between vegetable consumption and preferences $(p=0.001, R P=5.47)$, and availability $(p=0.173)$. There is a relationship between fruit consumption and preferences $(p=0.001, R P=2.47)$, and availability $(p=$ 0.006, $R P=2.79)$. Researchers suggest to families, especially parents, to increase the willingness of vegetables and fruit every day at home to form adolescent preferences for vegetables and fruit.

Keywords: passions, availability, consumption of vegetables and fruit

\section{PENDAHULUAN}

Orang yang diharapkan makan sayur dan buah adalah setiap anggota rumah tangga terutama usia 10 tahun ke atas. Minimal setiap anggota rumah tangga mengosumsi 2 porsi sayur dan 3 porsi buah atau sebaliknya setiap hari. Anjuran mengosumsi sayur dan buah setiap hari ini sangat penting karena mengandung vitamin dan mineral yang mengatur pertumbuhan dan pemeliharaan tubuh dan karena mengandung serat yang tinggi (Maryunani, 2015).

Sayur merupakan sumber vitamin A, vitamin $\mathrm{C}$, asam folat, magnesium, kalium dan serat serta tidak mengandung lemak dan kolesterol. Sayuran daun berwarna hijau, dan sayuran berwarna jingga seperti wortel dan tomat mengandung lebih banyak provitamin A berupa betakaroten dari pada sayuran tidak berwarna. Sayuran berwarna hijau kaya akan kalsium, zat besi, asam folat, dan vitamin C. Contoh sayuran berwarna hijau adalah bayam, kangkung, daun singkong, daun kacang, daun katuk dan daun pepaya. Semakin hijau warna daun, semakin kaya akan zat-zat gizi. Sayur juga dikonsumsi untuk memberi rasa segar dan melancarkan proses menelan makanan karena biasanya sayur dihidangkan dalam bentuk kuah. Porsi 
sayuran dalam bentuk tercampur yang dianjurkan sehari untuk orang dewasa adalah sebanyak 150-200 gram (Almatsier, 2016).

Khusus pada masa remaja yang merupakan periode dari pertumbuhan dan proses kematangan manusia, konsumsi sayur dan buah perlu sekali. Hal ini karena pada masa ini terjadi perubahan pertumbuhan yang sangat unik dan berkelanjutan. Perubahan fisik karena pertumbuhan yang terjadi akan mempengaruhi status kesehatan dan gizinya. Masalah gizi pada remaja akan berdampak negatif pada tingkat kesehatan masyarakat misalnya penurunan konsentrasi belajar dan penurunan kesegaran jasmani (Hasdianah et al, 2014).

Sayur dan buah pada remaja bermanfaat untuk menunjang tumbuh kembangnya dan status gizi yang baik. Faktanya, remaja saat ini cenderung kurang mengonsumsi sayur dan buah sehingga berisiko mengalami penyakit degeneratif seperti obesitas, diabetes, hipertensi dan kanker yang biasanya muncul di usia dewasa. Menurut Marmi (2016), bahwa pada manusia usia remaja memerlukan sayuran dan buah sebagai penghasil serta yang fungsinya untuk memungkinkan proses buang air besar menjadi teratur dan menghindari penyakit. Serat juga dapat memberi rasa kenyang dalam waktu lama.

Hasil penelitian Emilia (2009), menyatakan bahwa kekurangan gizi pada remaja akan mengakibatkan menurunnya daya tahan tubuh terhadap penyakit degeneratif sejak dini seperti: obesitas, diabetes, hipertensi dan kanker. Penelitian Peltzer dan Pengpid (2012), menemukan bahwa kecukupan konsumsi sayur dan buah pada remaja di lima Asia Tenggara (India, Indonesia, Myanmar, Sri Lanka, dan Thailand) merupakan salah satu perlindungan untuk mencegah overweight atau obesitas.

Gizi seimbang bagi remaja adalah makanan yang dikonsumsi remaja yang mengandung zat sumber tenaga, zat pembangun, dan zat pengatur serta beraneka ragam jenisnya. Kebutuhan zat gizi usia remaja dipengaruhi faktor antara lain: 1) pada anak usia sekolah banyak mengikuti aktivitas fisik maupun mental, seperti bermain, belajar dan berolahraga; 2) lingkungan; 3) pengobatan; 4) depresi dan kondisi mental; 5) penyakit, zat gizi akan membantu meningkatkan kesehatan tubuh anak, sehingga sistem pertahanan tubuhnya pun baik dan tidak mudah terserang penyakit; dan 6) stress (Hasdianah et al, 2014).

Menurut Riset Kesehatan Dasar (Riskedas) di Indonesia tahun 2013, penduduk dikategorikan "cukup" mengonsumsi sayur dan/atau buah apabila makan sayur dan/atau buah minimal 5 porsi per hari selama 7 hari dalam seminggu. Dikategorikan "kurang" apabila konsumsi sayur dan/atau buah kurang dari ketentuan di atas. Informasi frekuensi dan porsi asupan sayur dan buah ini dikumpulkan dengan menghitung jumlah hari konsumsi dalam seminggu dan jumlah porsi rata-rata dalam sehari. Berdasarkan data dari tahun 20072013 menunjukkan data yang sama sehingga dapat dilakukan analisis kecenderungan proporsi penduduk umur $\geq 10$ tahun yang mengonsumsi kurang sayur dan buah yaitu penduduk umur $\geq 10$ tahun secara nasional rata-rata sebesar 93,7\%. Khusus di Provinsi Sumatera Utara terjadi penurunan sedikit dari tahun 2007 sampai 2013 sebesar 93,5\% menjadi 92,5\% (Kemenkes, 2013).

Penelitian Mandira dan Indrawani (2014) tentang konsumsi buah dan sayur menurut karakteristik responden, pengaruh teman sebaya, ketersediaan dan keterpaparan media massa pada siswa di SMA Negeri 115 Jakarta tahun 2013 menemukan 42,3\% responden yang mengonsumsi sayur dan buah memenuhi anjuran gizi seimbang. Penelitian juga menemukan bahwa ada hubungan antara sikap dengan konsumsi buah dan sayur pada remaja.

Menurut Proverawati \& Rahmawati (2016), keluarga memiliki peran penting dalam mewujudkan kebiasaan makan sayur dan buah antara lain melalui kegiatan menyediakan sayur dan buah setiap hari di rumah, memperkenalkan sejak dini kepada anak kebiasaan makan sayur dan buah pagi, siang dan malam, dan memanfaatkan setiap kesempatan di rumah untuk mengingatkan tentang pentingnya makan sayur dan buah. Berdasarkan survei Nurdin et al (2015), diketahui bahwa terdapat lima jenis buahbuahan yang paling banyak dikonsumsi oleh rumah tangga yaitu pisang, pepaya, semangka, salak, dan alpukat. Diduga karena harga yang relatif murah, sehingga terjangkau oleh setiap lapisan masyarakat. 
Berbagai temuan penelitian sebelumnya menunjukkan beberapa faktor yang mempengaruhi atau berhubungan dengan konsumsi sayur dan buah pada remaja antara lain pendapatan keluarga/status ekonomi, teman sebaya, ketersediaan dan keterpaparan media massa. Berkaitkan dengan penelitian ini, peneliti ingin mengetahui faktor-faktor yang berhubungan dengan konsumsi sayur dan buah pada siswa sekolah SMK Negeri 1 Percut Sei Tuan Kabupaten Deli Serdang.

Survei awal di SMK Negeri 1 Percut Sei Tuan Kabupaten Deli Serdang diperoleh data jumlah siswa kelas X dan kelas XI Jurusan Rekayasa Perangkat Lunak sebanyak 97 orang terdiri dari 38 orang laki-laki dan 59 orang perempuan. Hasil wawancara dengan 18 siswa (10 orang laki-laki dan 8 orang perempuan), diperoleh informasi sebanyak 8 orang laki-laki kurang mengonsumsi sayur dan buah $(80 \%)$. Sementara dari siswa perempuan sebanyak 3 orang menyatakan kurang mengonsumsi sayur dan buah $(37,5 \%)$. Berbagai alasan penyebab siswa kurang mengonsumsi sayur dan buah yaitu tidak suka sayur dan buah, keluarga tidak rutin menyediakan sayur dan buah dengan alasan ekonomi, kantin sekolah juga tidak rutin menyediakan sayur dan buah, sayuran yang disediakan tidak disukai siswa dan sebagainya.

Berdasarkan uraian latar belakang dan fenomena di lokasi penelitian maka peneliti ingin melakukan penelitian tentang hubungan kesukaan dan ketersediaan dengan konsumsi sayur dan buah pada siswa SMK Negeri 1 Percut Sei Tuan Kabupaten Deli Serdang.

\section{METODE PENELITIAN}

Tujuan penelitian untuk menguji hubungan kesukaan dan ketersediaan dengan konsumsi sayur dan buah pada remaja. Penelitian ini menggunakan desain cross sectional. Populasi siswa kelas $\mathrm{X}$ dan kelas XI Jurusan Rekayasa Perangkat Lunak SMK Negeri 1 Percut Sei Tuan Kabupaten Deli Serdang diperoleh data jumlah sebanyak 97 responden (38 orang laki-laki dan 59 orang perempuan) dengan menggunakan total sampling. Alat pengumpulan data menggunakan kuesioner kesukaan dan ketersediaan. Analisis data menggunakan uji chi square.

\section{HASIL}

Tabel 1. Karakteristik Remaja Berdasarkan Umur, Jenis Kelamin, Suku Bangsa, Agama, dan Jumlah Anggota Keluarga pada Remaja di SMK Negeri 1 Percut Sei Tuan Kabupaten Deli Serdang

\begin{tabular}{|c|c|c|c|}
\hline No. & Karakteristik & $\mathbf{n}$ & $\%$ \\
\hline 1. & \multicolumn{3}{|l|}{ Umur } \\
\hline & 15 Tahun & 20 & 20,6 \\
\hline & 16 Tahun & 52 & 53,6 \\
\hline & 17 Tahun & 25 & 25,8 \\
\hline & Total & 97 & 100 \\
\hline 2. & \multicolumn{3}{|l|}{ Jenis Kelamin } \\
\hline & Laki-laki & 38 & 39,2 \\
\hline & Perempuan & 59 & 60,8 \\
\hline & Total & 97 & 100 \\
\hline 3. & \multicolumn{3}{|l|}{ Suku Bangsa } \\
\hline & Jawa & 50 & 51,5 \\
\hline & Batak & 30 & 30,9 \\
\hline & Melayu & 17 & 17,5 \\
\hline & Total & 97 & 100 \\
\hline 4. & \multicolumn{3}{|l|}{ Agama } \\
\hline & Islam & 71 & 73,2 \\
\hline & Kristen Protestan & 18 & 18,6 \\
\hline & Khatolik & 8 & 8,2 \\
\hline & Total & 97 & 100 \\
\hline 5. & \multicolumn{3}{|c|}{ Jumlah Anggota Keluarga } \\
\hline & 2-4 orang & 36 & 37,1 \\
\hline & $>4$ orang & 61 & 62,9 \\
\hline (A) & Total & 97 & 100 \\
\hline
\end{tabular}

Tabel 2. Distribusi Frekuensi Kesukaan Remaja Terhadap Sayur dan Buah di SMK Negeri 1 Percut Sei Tuan Kabupaten Deli Serdang

\begin{tabular}{lcc}
\hline Kesukaan Sayur & n & \% \\
\hline Suka & 67 & 69,1 \\
\hline Tidak suka & 30 & 30,9 \\
\hline Kesukaan Buah & & \\
\hline Suka & 74 & 76,3 \\
\hline Tidak suka & 23 & 23,7 \\
\hline Total & 97 & 100 \\
\hline
\end{tabular}

Dari tabel 2 diatas dapat dilihat bahwa dari 97 responden, berdasarkan kesukaan sayur sebagian besar adalah kategori suka sayur sebanyak 67 orang $(69,1 \%)$ dan kategori buah sebagian besar adalah kategori suka buah sebanyak 30 orang $(30,9 \%)$.

Tabel 3. Distribusi Frekuensi Ketersediaan Sayur dan Buah di Rumah Remaja dan SMK Negeri 1 Percut Sei Tuan Kabupaten Deli Serdang

\begin{tabular}{lcc}
\hline Ketersediaan sayur & $\mathbf{n}$ & $\mathbf{\%}$ \\
\hline Tersedia & 95 & 97,9 \\
\hline Tidak tersedia & 2 & 2,1 \\
\hline
\end{tabular}




\section{Ketersediaan buah}

\begin{tabular}{lll}
\hline Tersedia & 83 & 85,6 \\
\hline Tidak tersedia & 14 & 14,4 \\
\hline Total & 97 & 100 \\
\hline
\end{tabular}

Dari tabel 3 diatas dapat dilihat bahwa dari 97 responden, berdasarkan ketersediaan sayur sebagian besar adalah kategori tersedia sayur sebanyak 95 orang $(97,9 \%)$ dan ketersediaan buah sebagian besar adalah kategori tersedia buah sebanyak 83 orang $(85,6 \%)$

Tabel 4. Distribusi Frekuensi onsumsi Sayur dan Buah Remaja di SMK Negeri 1 Percut Sei Tuan Kabupaten Deli Serdang

\begin{tabular}{lcc}
\hline $\begin{array}{l}\text { Konsumsi Pangan } \\
\text { Sayur dan Buah }\end{array}$ & n & \% \\
\hline Konsumsi sayur & & \\
\hline Cukup & 67 & 69,1 \\
\hline Kurang & 30 & 30,9 \\
\hline Konsumsi buah & & \\
\hline Cukup & 35 & 36,1 \\
\hline Kurang & 62 & 63,9 \\
\hline Total & 97 & 100 \\
\hline
\end{tabular}

Dari tabel 4 diatas dapat dilihat bahwa dari 97 responden, berdasarkan konsumsi sayur sebagian besar adalah kategori cukup sebanyak 67 orang $(69,1 \%)$ dan kategori kurang sebanyak 30 orang $(30,9 \%)$. Berdasarkan konsumsi buah sebagian besar adalah kategori kurang sebanyak 60 orang $(61,9 \%)$ dan kategori cukup sebanyak 37 orang $(38,1 \%)$. Konsumsi pangan sayur dan buah siswa SMK Negeri 1 Percut Sei Tuan Kabupaten Deli Serdang. Prevalensi konsumsi sayur sebagian besar siswa dengan ketersediaan sayur tersedia sebesar $70,5 \%$ dari kategori cukup, sedangkan sebagian besar siswa dengan ketersediaan sayur tidak tersedia sebesar $100 \%$ dari kategori kurang. Secara statistik didapatkan $p>0,05$ yang berarti bahwa tidak terdapat hubungan yang signifikan antara uang jajan dan ketersediaan sayur dengan kecukupan konsumsi sayur.

Tabel 5. Hubungan Kesukaan dan ketersediaan dengan Konsumsi Sayur di SMK Negeri 1 Percut Sei Tuan Kabupaten Deli Serdang

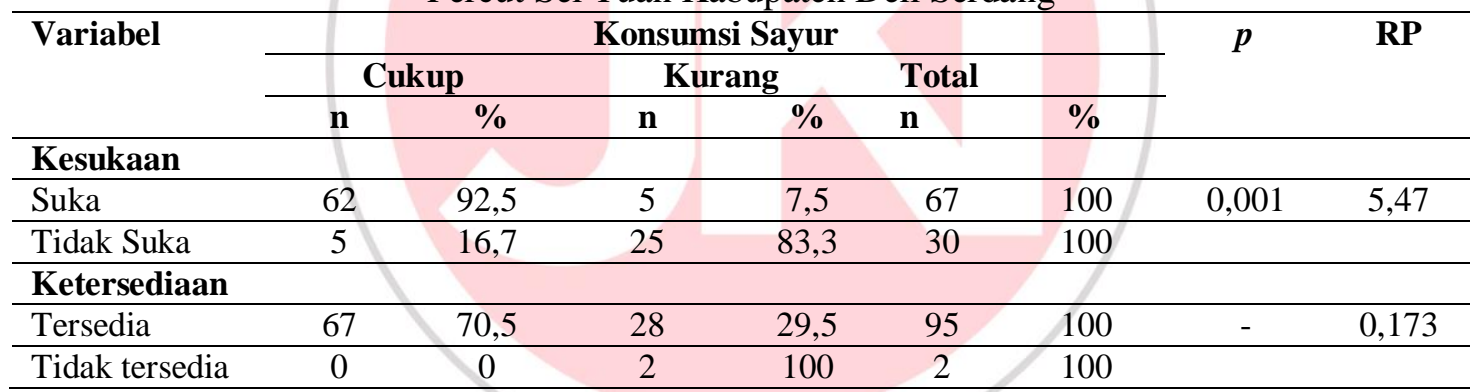

Dari tabel 5 diatas dapat dilihat bahwa $p<0,05$ yang berarti bahwa terdapat prevalensi konsumsi sayur sebagian besar siswa dengan suka konsumsi sayur sebesar 92,5\% dari kategori cukup, sedangkan sebagian besar siswa dengan tidak suka mengonsumsi sayur sebesar 83,3\% dari kategori kurang. Secara statistik didapatkan hubungan yang signifikan antara kesukaan siswa dengan kecukupan konsumsi sayur. Nilai RP diperoleh sebesar 5,47 artinya siswa yang suka sayur berpeluang 5,47 mengonsumsi sayur cukup dibandingkan dengan siswa yang tidak suka sayur.

Tabel 6. Hubungan Kesukaan dan ketersediaan dengan Konsumsi Buah di SMK Negeri 1 Percut Sei Tuan Kabupaten Deli Serdang

\begin{tabular}{|c|c|c|c|c|c|c|c|c|}
\hline \multirow[t]{3}{*}{ Variabel } & \multicolumn{6}{|c|}{ Konsumsi Buah } & \multirow[t]{3}{*}{$p$} & \multirow[t]{3}{*}{$\mathbf{R P}$} \\
\hline & \multicolumn{2}{|c|}{ Cukup } & \multicolumn{2}{|c|}{ Kurang } & \multicolumn{2}{|c|}{ Total } & & \\
\hline & $\mathbf{n}$ & $\%$ & $\mathbf{n}$ & $\%$ & n & $\%$ & & \\
\hline \multicolumn{9}{|l|}{ Kesukaan } \\
\hline Suka & 31 & 41,9 & 43 & 58,1 & 74 & 100 & 0,001 & 2,47 \\
\hline Tidak Suka & 4 & 17,4 & 19 & 82,6 & 23 & 100 & & \\
\hline \multicolumn{9}{|l|}{ Ketersediaan } \\
\hline Tersedia & 33 & 39,8 & 50 & 60,2 & 83 & 100 & 0,006 & 2,79 \\
\hline Tidak tersedia & 2 & 14,3 & 12 & 85,7 & 14 & 100 & & \\
\hline
\end{tabular}


Dari tabel 6 diatas dapat dilihat bahwa prevalensi konsumsi buah sebagian besar siswa dengan suka konsumsi buah sebesar 41,9\% dari kategori cukup, sedangkan sebagian besar siswa dengan tidak suka mengonsumsi buah sebesar $82,6 \%$ dari kategori kurang. Secara statistik didapatkan $p<0,05$ yang berarti bahwa terdapat hubungan yang signifikan antara kesukaan siswa dengan kecukupan konsumsi buah. Nilai RP diperoleh sebesar 2,47 artinya siswa yang suka buah berpeluang 2,47 mengonsumsi buah cukup dibandingkan dengan siswa yang tidak suka buah. Prevalensi kecukupan konsumsi buah siswa dengan ketersediaan buah sebagian besar tersedia sebesar 39,8\% dari kategori cukup, sedangkan sebagian besar siswa dengan ketersediaan buah tidak tersedia sebesar 85,7\% dari kategori kurang. Secara statistik didapatkan $p<0,05$ yang berarti bahwa terdapat hubungan yang signifikan antara ketersediaan buah dengan kecukupan konsumsi buah. Nilai RP diperoleh sebesar 2,79 artinya siswa yang memiliki keluarga dengan ketersediaan buah tersedia berpeluang 2,79 mengonsumsi buah cukup dibandingkan dengan siswa yang memiliki keluarga dengan ketersediaan buah tidak tersedia.

\section{PEMBAHASAN}

\section{Hubungan Kesukaan Remaja dengan Konsumsi Sayur dan Buah}

Berdasarkan uji analisis bivariat, menunjukkan ada hubungan antara kesukaan siswa dengan konsumsi sayur $(p=0,001, \mathrm{RP}$ $=5,47$ ), nilai $\mathrm{RP}$ diperoleh sebesar 5,47 artinya siswa yang suka sayur berpeluang 5,47 mengonsumsi sayur cukup dibandingkan dengan siswa yang tidak suka sayur. Ada hubungan yang signifikan antara kesukaan siswa dengan kecukupan konsumsi buah $(p=0,001, \mathrm{RP}=2,47)$, nilai $\mathrm{RP}$ diperoleh sebesar 2,47 artinya siswa yang suka buah berpeluang 2,47 mengonsumsi buah cukup dibandingkan dengan siswa yang tidak suka buah.

Kesukaan makanan termasuk sayur dan buah berkaitan pada daya terima dari makanan tersebut, yang dipengaruhi oleh kebiasaan, kualitas rasa dan zat gizi yang terkandung dalam makanan tersebut. Kesukaan dapat berubah dari waktu ke waktu atau menetap. Selain itu kesukaan makanan juga dapat berbeda di antara kelompok umur dan jenis kelamin. Kelompok remaja dan dewasa lebih suka untuk memilih makanan yang dikonsumsinya sendiri, dan pada kelompok remaja biasanya kurang begitu peduli dengan kandungan gizi yang tinggi pada makanan dan cenderung lebih menyukai makanan yang sedang trend (Hardinsyah, 2013).

Berdasarkan hasil penelitian Bahria dan Triyanti (2010), menemukan bahwa ada hubungan antara kesukaan terhadap sayur dan buah dengan konsumsi sayur dan buah dikarenakan kesukaan terhadap makanan mempunyai pengaruh terhadap pemilihan makanan. Pada penelitian Peltzer dan Pengpid (2012), menunjukkan hubungan antara preferences dan outcome expectations. Sejalan dengan penelitian Sianturi et al (2018), menunjukkan ada hubungan antara kesukaan (preferensi) dan konsumsi sayur. Sayur merupakan makanan yang tidak bisa langsung dikosumsi tanpa pengolahan. Oleh karena itu, teknik pengolahan sayur dapat berperan dalam mempengaruhi rasa sayur yang pada akhirnya dapat menentukan seseorang makan sayur tersebut atau tidak. Rasa merupakan suatu faktor penting dalam pemilihan pangan yang meliputi aroma, tekstur dan suhu. Oleh karena itu rasa sayur dan buah dapat mempengaruhi seseorang dalam mengonsumsi sayur dan buah, enak atau tidaknya sayur tergantung dari teknik pengelolaannya, sedangkan buah tergantung juga teknik penyajiaannya.

Sedangkan penelitian Nenobanu et al (2018), menunjukkan tidak ada hubungan antara kesukaan terhadap sayur dan buah dengan konsumsi sayur dan buah. Hasil wawancara singkat pada penelitian tersebut bahwa, sebagian besar responden suka makan sayur dan buah. Namun, inisiatif untuk membeli atau bahkan mengolah bahan makanan tersebut jarang. Mereka memiliki alasan bahwa sibuk dengan tugas kuliah dan berbagai macam kegiatan ekstra sehingga mereka lebih memilih untuk membeli makanan siap saji seperti ayam goreng, bakwan, mie instan dan jarang mengonsumsi buah dan sayur.

Sikap suka atau tidak suka terhadap pangan hanyalah salah satu alasan yang membentuk preferensi pangan. Preferensi dapat diartikan sebagai tingkatan kesukaan. 
Maksudnya, tingkat kesukaan secara kualitas dan atau bila dibandingkan dengan tingkat kesukaan terhadap sesuatu yang lain (Febrianti, 2012). Preferensi pangan lebih menunjuk pada keadaan ketika seseorang harus melakukan pilihan terhadap pangan dengan menunjukkan reaksi penerimaan atau rasa makanan yang datanya diukur (Febrianti, 2012). Suatu makanan tidak akan disukai bila belum pernah dicoba. Selain itu, suatu makanan bisa tidak disukai jika setelah dicoba terasa membosankan, terlalu biasa dikonsumsi, menyebabkan alergi atau reaksi fisiologis, dan berhubungan dengan jika ada efek penyakit setelah mengonsumsi pangan tersebut.

Berdasarkan hasil penelitian dapat disimpulkan bahwa siswa atau remaja yang suka dengan sayur dan buah akan mempengaruhi kecukupan konsumsi sayur dan buah. Kesukaan sayur dan buah akan menimbulkan inisiatif yang tinggi untuk membeli atau bahkan mengolah sayur dan menyajikan buah yang disukai sehingga meningkatkan kecukupan sayur dan buah. Rasa sayur dan buah juga dapat mempengaruhi seseorang dalam kesukaan mengonsumsi sayur dan buah, enak atau tidaknya sayur tergantung dari teknik pengelolaannya, sedangkan buah tergantung juga teknik penyajiaannya. Dalam hal ini keluarga berperan untuk mengolah sayuran dan menyajikan buah-buahan yang enak untuk meningkatkan kesukaan remaja terhadap sayur dan buah.

\section{Hubungan Ketersediaan dengan Konsumsi Sayur dan Buah}

Berdasarkan uji analisis bivariat, menunjukkan tidak ada hubungan antara uang jajan siswa dengan konsumsi sayur. Secara statistik didapatkan $p>0,05$ yang berarti bahwa tidak terdapat hubungan yang signifikan antara ketersediaan sayur dengan kecukupan konsumsi sayur.

Ketersediaan pangan merupakan bagian pertama menuju arah konsumsi pangan sebab tidak mungkin kita mengonsumsi suatu makanan yang tidak tersedia. Ketersediaan pangan yang kurang dapat mengurangi konsumsi pangan, yang akhirnya dapat menimbulkan masalah gizi kurang. Ketersediaan merupakan salah satu faktor eksternal perilaku konsumsi atau makan remaja selain peran orang tua.
Hal tersebut terlihat dari hasil penelitian Bahria dan triyanti (2010), setelah dilakukan tabulasi silang antara ketersediaan sayur dengan kesukaan sayur diperoleh remaja yang dirumahnya tersedia sayur setiap hari cenderung lebih banyak yang suka sayur $(77,4 \%)$, sedangkan yang tidak tersedia sayur setiap hari sebanyak $76,9 \%$ remaja yang suka sayur. Dilihat dari kebiasaan orang tua yang makan sayur setiap hari cenderung responden yang suka sayur $(79,8 \%)$, sedangkan orang tua yang tidak terbiasa makan sayur sebanyak 65,9\% remaja yang suka sayur. Demikian juga orang tua yang pernah menganjurkan makan sayur sebanyak $77,7 \%$ remaja suka sayur sedangkan sebanyak 33,3\% responden suka sayur pada orang tua yang tidak pernah menganjurkan makan sayur dan buah. Dari hasil penelitian Bahria dan Triyanti (2010), peneliti mengasumsikan bahwa konsumsi sayur dapat dipengaruhi oleh kesukaan terhadap sayur kemudian didukung pula dari faktor lingkungan remaja berupa ketersediaan sayur dan peran orang tua dalam memberi contoh dan menganjurkan konsumsi sayur.

Sedangkan hasil penelitian Pearce et al (2012), menyatakan bahwa ada hubungan kedekatan akses supermarket dengan peningkatan konsumsi sayur. Sejalan dengan penelitian Rachman et al (2017) dan Sianturi et al (2018), menunjukkan bahwa terdapat hubungan yang signifikan yaitu semakin tinggi ketersediaan sayur maka semakin tinggi pula konsumsi sayur seseorang.

Namun ada faktor lain yang mempengaruhi ketersediaan sayur di rumah yaitu status ekonomi keluarga. Menurut Budiman dan Riyanto (2013), bahwa status ekonomi seseorang juga akan menentukan tersedianya suatu fasilitas yang diperlukan untuk kegiatan tertentu, sehingga status sosial ekonomi ini akan mempengaruhi seseorang dalam konsumsi makanan yang termasuk kebutuhan utama manusia.

Berdasarkan hasil penelitian dapat disimpulkan bahwa ketersediaan sayur tidak ada hubungan dengan konsumsi sayur. Tidak terdapatnya hubungan konsumsi sayur pada remaja dalam penelitian ini karena ada faktor lain yang lebih berpengaruh pada remaja yaitu kesukaan terhadap sayur, jadi walaupun sayur selalu tersedia di lingkungan termasuk rumah dan sekolah setiap hari jika 
remaja tidak suka sayur, maka konsumsi sayur tidak akan cukup. Sedangkan terdapatnya hubungan konsumsi buah pada remaja dalam penelitian ini karena secara ekonomi buah termasuk kedalam kategori pangan yang lebih mahal dari sayuran dengan pendapatan rumah tangga perbulan meningkat maka ketersediaan buah akan meningkat (status ekonomi merupakan salah satu faktor yang mempengaruhi ketersediaan), sehingga konsumsi buah juga akan meningkat.

Berdasarkan uji analisis bivariat, menunjukkan ada hubungan antara uang jajan siswa dengan konsumsi buah ( $p=$ $0,006, \mathrm{RP}=2,79$ ), nilai RP diperoleh sebesar 2,79 artinya siswa yang memiliki keluarga dengan ketersediaan buah tersedia berpeluang 2,79 mengonsumsi buah cukup dibandingkan dengan siswa yang memiliki keluarga dengan ketersediaan buah tidak tersedia.

Berdasarkan hasil penelitian Pearce et al (2012), menyatakan bahwa ada hubungan kedekatan akses supermarket dengan peningkatan konsumsi buah. Hasil penelitian Bahria dan Triyanti (2010), menyatakan bahwa ada hubungan antara ketersediaan buah dengan konsumsi buah pada remaja. Sejalan dengan penelitian Rachman et al (2017) dan Sianturi et al (2018), menunjukkan bahwa terdapat hubungan yang signifikan yaitu semakin tinggi ketersediaan buah maka semakin tinggi pula konsumsi buah seseorang.

Berdasarkan hasil penelitian dapat disimpulkan bahwa ketersediaan buah ada hubungan dengan konsumsi buah. Ada hubungan konsumsi buah pada remaja dalam penelitian ini karena secara ekonomi buah termasuk kedalam kategori pangan yang lebih mahal dari sayuran dengan pendapatan rumah tangga perbulan meningkat maka ketersediaan buah akan meningkat (status ekonomi merupakan salah satu faktor yang mempengaruhi ketersediaan), sehingga konsumsi buah juga akan meningkat.

Salah satu upaya untuk meningkatkan konsumsi sayur dan buah pada remaja adalah dengan penyediaan sayur dan buah baik dirumah, sekolah, dan rumah makan atau restaurant maupun pasar. Banyaknya jenis sayuran dan buah yang tersedia memungkinkan remaja untuk mengkonsumsinya, sedangkan makanan yang tidak tersedia tidak akan dikonsumsi orang (Pearce et al, 2012).

\section{KESIMPULAN}

Berdasarkan hasil penelitian dapat disimpulkan ada hubungan yang signifikan antara kesukaan remaja dengan konsumsi sayur dan tidak ada hubungan antara ketersediaan sayur. Ada hubungan yang signifikan antara kesukaan dan ketersediaan di rumah dan SMK Negeri 1 Percut Sei Tuan Kabupaten Deli Serdang. Hasil analisis diperoleh antara kesukaan dan konsumsi sayur Rasio Prevalensi $(\mathrm{RP})=5,47$ artinya remaja yang suka sayur mempunyai potensi 5,47 kali remaja mengkonsumsi sayur dibandingkan dengan remaja yang tidak suka sayur. Hasil antara kesukaan $(\mathrm{RP}=2,47)$ dan ketersedian $(\mathrm{RP}=2,79)$ konsumsi buah artinya remaja yang suka buah mempunyai potensi 2,47 dan 2,79 kali remaja mengkonsumsi buah dibandingkan dengan remaja yang tidak suka buah.

\section{DAFTAR PUSTAKA}

Almatsier, S. (2016). Prinsip Dasar Ilmu Gizi. Jakarta: PT Gramedia Pustaka Utama.

Badan Penelitian dan Pengembangan Kesehatan. (2013). Riset Kesehatan Dasar (Riskesdas) 2013 Laporan Nasional. Jakarta: Badan Penelitian dan Pengembangan Kesehatan.

Bahria., \& Triyanti. (2010). Faktor-Faktor yang Terkait dengan Konsumsi Buah dan Sayur pada Remaja di SMA 4 Jakarta Barat. Jurnal Kesehatan Masyarakat, Maret 2010-September 2010, Vol. 4, No.2.

Budiman., \& Riyanto, A. (2013). Kapita Selekta Kuesiner Pengetahuan dan Sikap dalam Penelitian Kesehatan. Jakarta: Salemba Medika.

Emilia, E. (2009). Pengetahuan, Sikap, dan Praktek Gizi pada Remaja dan Implikasinya pada Sosialisasi Perilaku Hidup Sehat. Media Pendidikan, Gizi dan Kuliner, Vol. 1, No. 1, November 2009.

Febrianti, D. (2012). Penyelenggaraan Makanan, Tingkat Konsumsi dan analisis Preferensi Atlet di SMA Negeri Ragunan Jakarta. Fakultas Ekologi Manusia. Bogor: Institut Pertanian Bogor. 
Hardiansyah. (2013). Review Faktor Determinan Keragaman Konsumsi Pangan. Jurnal Gizi dan Pangan.

Hasdianah, H.R., Siyoto, S., \& Peristyowati, Y. (2014). Gizi-Pemanfaatan Gizi, Diet dan Obesitas. Cetakan Pertama. Yogyakarta: Nuha Medika.

Marmi. (2016). Gizi dalam Kesehatan Reproduksi. Cetakan Kedua. Yogyakarta: Pustaka Pelajar.

Maryunani, A. (2015). Perilaku Hidup Bersih dan Sehat (PHBS). Jakarta: Trans Info Media.

Nenobanu, A.I., Kurniasari, M.D., \& Rahardjo, M. (2018). Faktor-Faktor yang Berhubungan dengan Perilaku Konsumsi Buah dan Sayur pada Mahasiswi Asrama Universitas Kristen Satya Wacana. IJMS-Indonesia Journal on Medical Science-Volume 5 No. 1Januari 2018. ISSN 2443-1249 (Print) 2355-1313 (On Line)-ijmsbm.org.

Nurdin, S.U., Indriyani., \& Zuraida. (2015). Modifikasi Gaya Hidup Berbasis Sekolah untuk Meningkatkan Konsumsi Pitoseterol Anak Sekolah Dasar yang Mengalami Kelebihan Berat Badan di Bandar Lampung. Lembaga Penelitian Universitas Lampung. Bandar Lampung.

Pearce, J., Hiscock, R., Blakely, T., \& Witten, K. (2012). The Contextual Effects of Neighbourhood Access to Supermarkets and Convenience Stores on Individual Fruit and Vegetable Consumption. J. Epidemiol. Community Health 2012;62;198-201. doi: 10.1136/jech.2006.059196.

Peltzer, K., \& Pengpid, S. (2012). Fruit and Vegetables Consumption and Associated Factors among In-School Adolescents in Five Southesat Asian Countries. Int. J. Environ. Res. Public Health 2012, 9, 3575-3587. Doi: 103390/ijerph9103575.

Proverawati, A., \& Rahmawati, E. (2016). Perilaku Hidup Bersih dan Sehat (PHBS). Yogyakarta: Nuha Medika.

Rachman, B.N., Mustika, IG., \& Kusumawati, I.G.AW. (2017). Faktor yang Berhubungan dengan Perilaku Konsumsi Buah dan Sayur Siswa SMP di Denpasar. Jurnal Gizi Indonesia (The Indonesian Journal of Nutrition), 6(1),
2017. e-ISSN: 2338-3119. p-ISSN: 1858-4942.

Sianturi, E., Aritonang, EY., \& Sudaryati, E. (2018). Faktor-Faktor yang Berhubungan dengan Kebiasaan Konsumsi Sayur dan Buah pada Remaja yang Tinggal di Rumah kos di kota Tarutung Tahun 2017. Medan: FKM Universitas Sumatera Utara. 